\title{
Turmeric Extracts as a Protective Natural Compound Against Hepatotoxicity Induced by Lead Nitrate in Male Albino Rat Model
}

\author{
Abd El-Fattah Abd El-Fattah ${ }^{1}$, Medhat Abozid ${ }^{2}$, Kamal Mahmoud ${ }^{2 *}$ \\ 1- Ministry of Health and Population, Cairo, Egypt. \\ 2- Biochemistry Department, Faculty of Agriculture, Menoufia University, Postal Code 32516, Mostafa \\ Kamel St., Eastern Bank, Shebin El-Kom, Menoufia, Egypt \\ * Corresponding author: esraamasria74@gmail.com
}

DOI:10.21608/ajs.2021.75154.1374

Received 4 May, 2021 ; Accepted 9 October, 2021

\section{Keywords:}

Turmeric, Lead nitrate, Liver function, Antioxidant, Extracts

\begin{abstract}
Excessive exposure to lead may damage the liver by increasing oxidative stress, leading to many serious diseases. Dietary antioxidants may protect the liver from damage. Therefore, the effect of ethanolic and aqueous turmeric extracts against lead-induced liver damage was evaluated by estimating liver function and antioxidant/oxidative stress biomarkers. Forty rats were divided into group (A) served as control, group (B) treated with 93 $\mathrm{mg} / \mathrm{kg}$ b.wt. lead nitrate, group (C) and group (D) treated as group B in addition to $400 \mathrm{mg} / \mathrm{kg}$ b.wt. of turmeric aqueous and ethanolic extracts, respectively. Group B showed a significant increase in the activities of alanine transaminase by 10 folds, aspartate transaminase by 9 folds, alkaline phosphatase by 3 folds and the level of malondialdehyde by 10 folds, while showed a significant decrease in albumin by $60 \%$, total protein by $54.5 \%$, and superoxide dismutase by $80.5 \%$, catalase by $75 \%$ and glutathione by $71.6 \%$ in comparison with control group. On the other hand, turmeric treatments (groups $\mathrm{C}$ and $\mathrm{D}$ ) led to readjustment of levels for such biomarkers. Collectively, these results demonstrate the potential of turmeric extracts (particularly the ethanolic extract) to improve the fatal effect of lead in a rat model.
\end{abstract}

\section{Introduction}

Heavy metals such as Lead $(\mathrm{Pb})$ are toxic material and harmful pollutants for water (KaradedeAkin and Unlï 2007). Their presence not only effect human beings but also animals and vegetation because of their mobility. Lead is known to cause many harmful physiological and biochemical changes in animals as well as in humans (Florea and Busselberg 2006, Ruff et al 1996).

In biological systems, lead affects many cellular components and organelles, such as the endoplasmic reticulum, cell membrane, nucleus, mitochondria, and many other enzymes. One of the toxic effects of this heavy metal is caused by the production of reactive oxygen species (ROS), which causes oxidative stress and ultimately leads to cell damage, especially liver cells (Wang and Shi 2001).

At the same time, the use of synthetic drugs to combat the toxic effect of these metals often becomes inappropriate due to their undesirable side effect especially when used either for long terms or when more than one of them used simultaneously because of drug interactions (Jaishankar et al 2014). It was therefore necessary to look for natural therapeutic sources which may reduce the harmful effects of these elements, and this makes attention to food plants rich in antioxidants increases (Abozid et al 2018). 
One of these plants is the turmeric (curcuma longa tinn) rhizomes which has pharmacological activities that include antioxidant, antiinflammatory, anticancer, immunomodulatory, neuroprotective, and antiaging effects (Pari and Prasath 2008). Curcumin is the most important compound in the turmeric plant in terms of therapeutic because of its positive effect as a natural antioxidant, as it has no negative side effects such as chemical drugs (Joe et al 2004, Mohajeri et al 2017). This study aims to evaluate the effect of ethanolic and aqueous extracts of turmeric rhizomes against lead on liver function tests and the antioxidant/oxidative stress biomarkers in rats.

\section{Materials and Methods}

\subsection{Plant collection and identification}

A bout $1 / 2 \mathrm{Kg}$ Rhizomes of turmeric (Curcuma longa tinn) were obtained from Agriculture Research Center in El-qnater El-khairia, Kaliobia, Egypt in September 2016. Rhizome were Identified in Horticulture department, Faculty of Agriculture, Menoufia University.

\subsection{Preparation aqueous and ethanolic extracts of turmeric}

The turmeric rhizomes were kept at room temperature in a dry place prior to use. About $50 \mathrm{~g}$ of air-dried rhizomes were powdered and extracted with five times volume of distilled water or ethanol $80 \%$ for $48 \mathrm{~h}$ with continuous shaking (Mukhtar and Ghori 2012). The final extracts were filtrated with filter paper Whatman №1, concentrated with a rotary evaporator at $50 \pm 1^{\circ} \mathrm{C}$ to give solid residues and stored at $4^{\circ} \mathrm{C}$ for further use.

\subsubsection{Determination of total phenolic com- pounds, total flavonoids and DPPH radical scavenging}

The concentration of total phenolic compounds in each extract was determined colorimetrically as gallic acid equivalent based on the gallic acid standard curve(GAE; mg gallic acid/100 g) by the method of Folin-Ciocalteu's as described by (Gulcin et al 2002), while the total flavonoids contents were determined and expressed as $\mathrm{mg}$ of quercetin (mg QCE/100 g) based on the quercetin standard curve using the method reported by (Dewanto et al 2002) and DPPH (2, 2-diphenyl -1pricrylhydrazyl) free radical was measured for aqueous or ethanolic extracts according to (Lee et al 1996).

\subsubsection{Determination of curcumin content in tur- meric}

Curcumin was separated and determined by using HPLC (A Shimadzu LC 20 AT HPLC), mobile phase was (acetonitrile / acetic acid/double distilled water 9/2/89 v/v/v), the column was 5- $\mu \mathrm{m} \mathrm{C18} \mathrm{column} \mathrm{(Wa-}$ ters, Milford, MA) and detector was SPD-20 UV Visible detector (At wavelength of $262 \mathrm{~nm}$ ) according to Zuo et al 2002.

\subsection{Biological experiment}

\subsubsection{Animals}

Forty male Wister albino rats $(120 \pm 10 \mathrm{~g})$ were obtained from Research Institute of "Laboratory Animals Research Center", Faculty of Veterinary Medicine, Benha University, Qalyubia, Egypt. All experimental procedures were completed according to the ethical guidelines of International Association for the Study of Pain (Zimmermann 1983).

Animals were placed in laboratory conditions for 15 days as an adaptation period. Water and food were always available throughout the experiment. Randomized groups of rats were housed in cages containing wood shaving as bedding, and were allocated into four groups (45 days), each having 10 male rats as follow: (A) control group without any treatment, (B) positive control group treated with $93 \mathrm{mg} / \mathrm{kg}$ b.wt. orally of lead nitrate, (C) treated with $93 \mathrm{mg} / \mathrm{kg}$ b.wt. orally of lead nitrate in addition to $400 \mathrm{mg} / \mathrm{Kg}$ b.wt. of water extract of turmeric, and (D) received $93 \mathrm{mg} / \mathrm{kg}$ b.wt. orally of lead nitrate in addition to $400 \mathrm{mg} / \mathrm{Kg}$ b.wt. of ethanolic extract of turmeric. At the end of experiment blood collected to further determination.

\subsubsection{Blood samples}

After 45 days of treatment period, the animals were deprived of food overnight and anesthetized and then sacrificed by cervical decapitation. Blood samples were collected from orbital sinus veins technique at the end of experimental period, into $(1.5 \mathrm{ml})$ Eppendorf tubes (contained heparin as anticoagulant).

Blood samples were centrifuged for $15 \mathrm{~min}$ at 3600 rpm in a refrigerated centrifuge to separate plasma. Plasma samples were kept in a deep freeze at $\left(-20^{\circ} \mathrm{C}\right)$, till the different assays were carried out.

\subsubsection{Biochemical analysis}

Kits for enzymes activity superoxide dismutase (SOD), catalase (CAT), alanine transaminase (ALT), aspartate transaminase (AST), alkaline phosphatase (ALP) and levels of total protein, albumin, glutathione 
(GSH) and malonaldehyde (MDA) purchased from the Bio-diagnostic Company, Cairo, Egypt.

Transaminases (ALT and AST) were measured according to Young 1990, while alkaline phosphatase (ALP) was determined in serum according to Moss et al (1987), also total protein was determined in plasma as described by Schultze and Heremans (1966) and albumin was measured in plasma as described by Kruijswijk (1975).

Malondialdehyde (MDA) was measured according to Ohkawa et al (1979) also, superoxide dismutase (SOD) activity was determined by using the method of Nishikimi et al (1972), catalase (CAT) activity was determined as described by Aebi (1984) and determination of glutathione (GSH) level was done according to the method of Goldberg and Spooner (1983).

\subsection{Statistical analysis}

Duncan's multiple range test was used to compare between the treatments means. The mean values within each column followed by same letters are not significantly different at $5 \%$.

\section{Results and Discussion}

3.1Total phenolic compounds and total flavonoids as well as DPPH-radical scavenging activity in aqueous and ethanolic extracts of turmeric

The obtained results as shown in Figure 1 clarified that ethanolic extract contains amount higher for both total phenolics content $(76.26 \mathrm{mg}$ GAE/100 g) and total flavonoids (46.7 mg/100 g) than aqueous extract where free phenolics content was $65.38 \mathrm{mg} / 100 \mathrm{~g}$ and total flavonoids were $29.5 \mathrm{mg} / 100 \mathrm{~g}$.

There are many factors that cause the quantity and type of phenolic compounds to differ in the same plant type, the most important of which are the soil type, growing conditions, harvesting methods and timing, and climatic conditions in which the cultivation took place (Jaffery et al 2003). Also, the extraction method represents an important qualitative factor in the amount and type of phenolic compounds in the final extract (Gallardo et al 2006).

It is clear from the results that the alcoholic extract was better than the aqueous extract in the effect as an antioxidant, which in turn is linked to its high content of phenolic compounds. Liu et al 2003 reported that the antioxidant activity of methanolic extract of turmeric was $6.3 \mathrm{mg} \mathrm{GAE} / \mathrm{g}$ dry weight of sample. In another study, the total phenolics in ethanolic extract of turmeric was $7.124 \mathrm{mg}$ GAE/g dry weight of sample (Shan et al 2005).

The DPPH method is one of the best in vitro methods that evaluate the antioxidant activity (radical scavenging) of different extracts because of its accuracy and simplicity Gallardo (2006).

Data in Table 1 showed that both of turmeric rhizome's extracts recorded more than $20 \%$ (inhibition $\%$ ) in DPPH assay, as well as $\mathrm{IC}_{50}$ for aqueous extract was $569.77 \mathrm{ppm}$ while the $\mathrm{IC}_{50}$ for ethanolic extract was $430.67 \mathrm{ppm}$. The increase in the DPPH activity of the ethanolic extract compared to the aqueous extract may be due to the presence of higher total phenolic and flavonoids contents in the former extract as shown in Figure 1. The varied results obtained for the same extract in DPPH method are due to the extreme sensitivity of this reaction to environment conditions $(\mathrm{pH}$, solvent purity, light exposure) (Schaich 2015).

\subsection{The curcumin content in turmeric}

The content of curcumin in ethanolic extract of turmeric was $19.2 \%$. This result is close to what both Yue et al 2016 and Li et al 2018 found in previous studies of turmeric rhizomes. Curcumin is the main ingredient in turmeric plant extracts and is largely responsible for many of the vital and healthy roles (Nouzarian et al 2011, Wang et al 2015, Nawab et al 2019).

\subsection{Effect turmeric ethanolic and aqueous extracts against lead on liver functions}

The obtained results as shown in Table 2 revealed that lead treatment (poisoned control groups) caused a significant increase in the activities of liver functions indicators in plasma (ALT, AST and ALP), while a significant decrease in synthetic liver functions (albumin and total protein levels) was observed, comparing with normal control group.

In contrast, administration ethanolic and aqueous extracts of turmeric showed pronounced decrease in AST, ALT, and ALP activities associated with an increase in total protein and albumin levels comparing with poisoned control and that ethanolic extract was more effective on the readjustment of all liver biomarkers than that of aqueous extract.

The liver is considered as the most organ of the body that is exposed to toxins (including heavy metals such as lead) (Meyer and Kulkarni 2001). Lead toxicity studies have shown that the liver stores the equivalent of $33 \%$ of the lead in experimental animals 


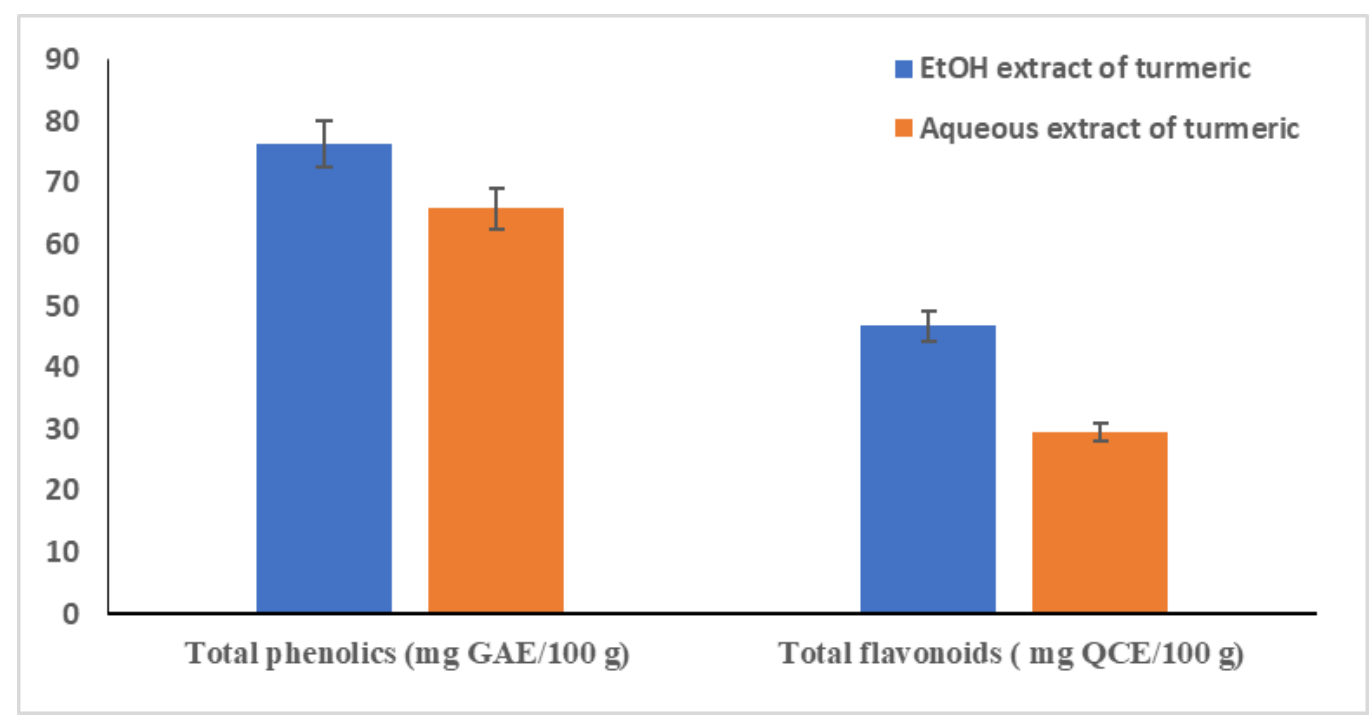

Fig 1. Total phenolic compounds and total flavonoids in turmeric aqueous and ethanolic extracts

Table 1. DPPH activity in turmeric aqueous and ethanolic extracts

\begin{tabular}{|c|c|c|c|c|c|c|c|}
\hline \multicolumn{2}{|c|}{} & \multicolumn{3}{c|}{ Turmeric aqueous extract } & \multicolumn{3}{c|}{ Turmeric ethanolic extract } \\
\hline \multirow{2}{*}{\begin{tabular}{c}
\hline \multirow{2}{*}{} \\
\cline { 2 - 8 }
\end{tabular}} & Concentration & $250 \mathrm{ppm}$ & $500 \mathrm{ppm}$ & $750 \mathrm{ppm}$ & $250 \mathrm{ppm}$ & $500 \mathrm{ppm}$ & $750 \mathrm{ppm}$ \\
\cline { 2 - 8 } & $\%$ Inhibition & 23.7 & 41.6 & 66.7 & 36 & 56.8 & 72.3 \\
\cline { 2 - 8 } & $\mathrm{IC}_{50}(\mathrm{ppm})$ & \multicolumn{3}{|c|}{569.77} & \multicolumn{3}{|c}{430.67} \\
\hline
\end{tabular}

Table 2. Plasma liver functions in rats supplemented with turmeric aqueous and ethanolic extracts against lead nitrate

\begin{tabular}{|r|r|r|r|r|r|}
\hline Groups & $\begin{array}{r}\text { AST } \\
(\mathrm{U} / \mathrm{L})\end{array}$ & $\begin{array}{r}\text { ALT } \\
(\mathrm{U} / \mathrm{L})\end{array}$ & $\begin{array}{r}\text { ALP }(\mathrm{U} / \mathrm{L}) \\
\text { Group A }\end{array}$ & $\begin{array}{r}\text { Total Protein } \\
(\mathrm{g} / \mathrm{dl})\end{array}$ & Albumin $(\mathrm{g} / \mathrm{dl})$ \\
\hline Group B & $129.1 \pm 1.47 \mathrm{~d}$ & $132.0 \pm 1.41 \mathrm{~d}$ & $201.8 \pm 2.31 \mathrm{~d}$ & $3.5 \pm 0.216 \mathrm{a}$ & $1.8 \pm 0.250 \mathrm{a}$ \\
\hline Group C & $111.3 \pm 1.63 \mathrm{c}$ & $98.0 \pm 1.41 \mathrm{c}$ & $187.5 \pm 1.87 \mathrm{c}$ & $4.3 \pm 0.231 \mathrm{~d}$ & $2.1 \pm 0.216 \mathrm{~d}$ \\
\hline Group D & $79.6 \pm 1.63 \mathrm{~b}$ & $74.0 \pm 1.41 \mathrm{~b}$ & $154.5 \pm 1.87 \mathrm{~b}$ & $5.1 \pm 0.216 \mathrm{c}$ & $3.0 \pm 0.216 \mathrm{c}$ \\
\hline
\end{tabular}

Each value represents a mean followed by standard deviation for 10 rats. $\mathbf{A}=$ Control group, $\mathbf{B}=$ Treated with lead nitrate $93 \mathrm{mg} / \mathrm{kg}$ b.wt., $\mathbf{C}=$ Treated as group B $+400 \mathrm{mg} / \mathrm{Kg}$ b.wt. of aqueous turmeric extract, $\mathbf{D}=$ Treated as group B $+400 \mathrm{mg} / \mathrm{Kg}$ b.wt. of ethanolic turmeric extract.

Different letters $(a, b, c$ and $d)$ in the same column indicate a significant deference $(p \leq 0.05)$, while same letter in different cells in the same column indicate a non-significant deference $(p \leq 0.05)$. 
compared to the rest of the soft tissues (Bechara 2004). One of the mechanisms that may explain how lead affects the liver depends on the idea of an imbalance between oxidants and antioxidants, which is called oxidative stress, which in turn leads to damage and breakdown of liver cells as a result of increased levels of free radicals (Liu et al 2013).

This study has recorded the occurrence of confirmed manifestations of damage to liver cells, and this was observed in the significant increase in activities of liver enzymes in the plasma (ALT, AST and ALP), which is consistent with what was published by many authors (Taib et al 2004, Liu et al 2012, Su et al 2017) about the association of the deterioration of liver cells and the increase in levels of liver enzymes in the plasma. Also, the structure of the protein which is altered by the destruction of the triangular shape because of lead, and that caused a decrease in the total protein level (Shalan et al 2005) and albumin levels (Lin et al 2016, Wu et al 2016).

Concerning the effect of curcumin against liver of rats affected by lead toxicity, the results showed that two curcumin extracts decreased the activity of liver enzymes activities (AST, ALT and ALP); these results, are supported by what many scientists have found about the positive effect of turmeric on improving the activities of liver enzymes in plasma when treated with different toxins (Kang et al 2009, Essam and Ashraf 2013, Palipoch et al 2014).
The improvement of the plasma levels of albumin and total protein when treated with the ethanol and aqueous extract of turmeric in the face of the harmful effect of lead is supported by the results of both Mathews et al 2012 and Garcia-Nino et al 2013.

In our expectation, the strong effect of the turmeric ethanolic extract on improving liver function is due to its high content of total phenolics and flavonoids (Figure 1).

Although the groups treated with turmeric extracts showed a significant and clear improvement in liver function parameters (Table 2), the values they showed were still far from the normal levels recorded in the control group. We believe that these results are promising and that it is possible to get closer to achieving normal levels of liver function parameters by increasing the duration of the experiment and increasing the doses used of turmeric extracts.

\subsection{Antioxidant and protective effects of turmeric against lead}

The effect of turmeric extracts supplementation against toxic effects of lead is presented in Table 3, where a variation between both controls and the other treated groups can notice. It can conclude that the activity of both SOD and CAT as well as levels of GSH in poisoned control group was the lowest except for MDA which behave inversely comparing with all other groups. The readjustment effect as a result of supplementation with turmeric extracts on the previous biomarkers could be observed clearly comparing with lead treated group after 45 days of treatments.

Table 3. Plasma antioxidant/oxidative stress parameters in rats supplemented with turmeric aqueous and ethanolic extracts against lead nitrate

\begin{tabular}{|c|c|c|c|c|}
\hline Groups & $\begin{array}{c}\text { MDA } \\
(\mathrm{nmol} / \mathrm{ml})\end{array}$ & $\begin{array}{c}\text { SOD } \\
(\mathrm{U} / \mathrm{L})\end{array}$ & $\begin{array}{c}\text { CAT } \\
(\mathrm{U} / \mathrm{L})\end{array}$ & $\begin{array}{c}\text { GSH } \\
(\mathrm{U} / \mathrm{ml})\end{array}$ \\
\hline Group A & $12.3 \pm 1.63 \mathrm{a}$ & $420.0 \pm 1.41 \mathrm{c}$ & $545.0 \pm 1.41 \mathrm{c}$ & $95.0 \pm 3.57 \mathrm{c}$ \\
\hline Group B & $126.3 \pm 1.50 \mathrm{~d}$ & $81.9 \pm 2.04 \mathrm{a}$ & $136.8 \pm 1.94 \mathrm{a}$ & $27.0 \pm 1.54 \mathrm{a}$ \\
\hline Group C & $113.0 \pm 1.41 \mathrm{c}$ & $127.3 \pm 1.63 \mathrm{~b}$ & $407.3 \pm 2.16 \mathrm{~b}$ & $61.8 \pm 1.47 \mathrm{~b}$ \\
\hline Group D & $82.0 \pm 1.41 \mathrm{~b}$ & $285.5 \pm 1.87 \mathrm{~d}$ & $506.6 \pm 2.58 \mathrm{~d}$ & $77.6 \pm 1.63 \mathrm{~d}$ \\
\hline
\end{tabular}

Each value represents a mean followed by standard deviation for 10 rats. $\mathbf{A}=$ Control group, $\mathbf{B}=$ Treated with lead nitrate $93 \mathrm{mg} / \mathrm{kg}$ b.wt., $\mathbf{C}=$ Treated as group $\mathrm{B}+400 \mathrm{mg} / \mathrm{Kg}$ b.wt. of aqueous turmeric extract, $\mathbf{D}=$ Treated as group B $+400 \mathrm{mg} / \mathrm{Kg}$ b.wt. of ethanolic turmeric extract.

Different letters ( $a, b, c$ and $d)$ in the same column indicate a significant deference $(p \leq 0.05)$, while same letter in different cells in the same column indicate a non-significant deference $(p \leq 0.05)$. 
These results are in accordance with those reported by many investigators (Tirkey et al 2005), as well as, that turmeric extracts increase SOD activity (Mary et al 2018), CAT activity (Eybl et al 2006) and GSH levels (Daniel et al 2004), while the levels of MDA were improved by strong antioxidants of turmeric (Daniel et al 2004), and that the ethanolic extract was the best in restoring antioxidants to their normal level.

The oxidative damage by lead led to increased generation of free radicals and caused direct impoverishment of antioxidants (Flora et al 2004), the body's primary front lines, the superoxide dismutase (SOD) and catalase (CAT) enzymes, control, and counter free radicals (Ferrari 2001). SOD converts superoxide radical (highly toxic) into hydrogen peroxide $\left(\mathrm{H}_{2} \mathrm{O}_{2}\right)$ ( $\mathrm{Li}$ et al 2013), then CAT complete the work by converting $\left(\mathrm{H}_{2} \mathrm{O}_{2}\right)$ into water molecule and oxygen (Hamadouche et al 2008). Glutathione (GSH) then works differently to resist toxic substances as it binds them to convert them into less dangerous compounds (Jurczuk et al 2006). The final product of the lipid peroxidation is MDA, whose level increases by increasing the oxidative stress (Abozid et al 2018).

The obtained results by Bokara et al 2008 showed that lead caused elevation in MDA and reduced the SOD activity (Wang et al 2012) and CAT (Han et al 2007), as well as, that the levels of GSH was decreased by lead treatment (Maiti and Chatterjee 2001). These results with numerous studies indicated that lead motivated oxidative stress in rats, possibly via the formation ROS (Hamadouche et al 2008), causing an increase in MDA levels, which is considered to be marker of lipid peroxidation (Bokara et al 2008).

Previous studies indicate the presence of the curcumin in polar solvents extracts, whether such as aqueous or alcoholic extracts as a major compound (Karioti et al 2011), which was found to have a very good effect as an antioxidant by scavenging free radicals or binding to heavy metals (Dinis et al 1994, Reddy and Lokesh 1994, Sreejayan and Rao 1994), which may explain many of the results of the current study.

\section{Conclusion}

From results of such study, it is obvious that lead nitrate caused elevation in the liver biomarkers (ALT, AST, and ALP activities) and (total protein and albumin levels), accompanied with an increased in MDA levels, together with marked decrees in antioxidant biomarker (SOD, CAT and GSH). All these effects can be ameliorated by turmeric (aqueous and ethanolic extract) treatment.

\section{References}

Abozid MM, Kamal EM, Abd El-Fattah AA (2018) Antioxidant and protective effects of green tea against $\mathrm{H}_{2} \mathrm{O}_{2}$ induced liver injury in rats. International Journal of Pharmaceutical Sciences Review and Research 50, 83-89.

Aebi H (1984) Catalase in Vitro. Methods in Enzymology 105, 121-126.

DOI:10.1016/s0076-6879(84)05016-3

Bechara EJH (2004) Lead poisoning and oxidative stress. Institute of de Quimica, Universidade de Sao Paulo, Brazil. SFRR`s 12th biennial meeting progamme and abstracts, May 5-9 (2004), Crown Plaza Panamericano Hotel Buenos Aires Argentina, S946, (36) Free Radic Biol Med; S22 pp.

Bokara KK, Brown E, McCormick R, Yallapragada PR, Rajanna S, Bettaiya R (2008) Lead-induced increase in antioxidant enzymes and lipid peroxidation products in developing rat brain. Biometals 21, 9-16. https://doi.org/10.1007/s10534-007-9088-5

Daniel S, Limson JL, Dairam A, Watkins GM, Daya S (2004) Through metal binding, curcumin protects against lead- and cadmium-induced lipid peroxidation in rat brain homogenates and against lead-induced tissue damage in rat brain. Journal of Inorganic Biochemistry 98, 266-75.

https://doi.org/10.1016/j.jinorgbio.2003.10.014

Dewanto V, Wu X, Adom KK, Liu RH (2002) Thermal processing enhances the nutritional value of tomatoes by increasing total antioxidant activity. Journal of Agricultural and Food Chemistry 50, 3010-4.

https://doi.org/10.1021/jf0115589

Dinis TC, Maderia VM, Almeida LM (1994) Action of phenolic derivatives (acetaminophen, salicylate, and 5-aminosalicylate) as inhibitors of membrane lipid peroxidation and as peroxyl radical scavengers. Archives of Biochemistry and Biophysics 315, 161-9.

https://doi.org/10.1006/abbi.1994.1485

Essam AM, Ashraf AE (2013) Effect of curcumin on hematological, biochemical and antioxidants parameters in Schistosoma mansoni infected mice. International Journal of Science 2, 1-12. 
Eybl V, Kotyzova D, Koutensky J (2006) Comparative study of natural antioxidants - curcumin, resveratrol and melatonin - in cadmium-induced oxidative damage in mice. Toxicology 225, 150-6. https://doi.org/10.1016/j.tox.2006.05.011

Ferrari CB (2001) Oxidative stress pathophysiology: Searching for an effective antioxidant protection. Internal Medicine Journal 8, 175-184.

Flora SJ, Pande M, Kannan GM, Mehta A (2004) Lead induced oxidative stress and its recovery following co-administration of melatonin or $\mathrm{N}$ acetylcysteine during chelation with succimer in male rats. Cellular and molecular biology (Noisyle-Grand)50 Online Pub: OL543-51. PMID: 15555419.

Florea AM, Büsselberg D (2006) Occurrence, use and potential toxic effects of metals and metal compounds. Biometals 19, 419-27.

doi: 10.1007/s10534-005-4451-x

Gallardo C, Jimenez L, Garcia-Conesa MT (2006) Hydroxycinnamic acid composition and in vitro antioxidant activity of selected grain fractions. Food Chemistry 99, 455-463. http://dx.doi.org/10.1016/j.foodchem.2005.07.053

García-Niño WR, Tapia E, Zazueta C, ZatarainBarrón ZL, Hernández-Pando R, Vega-García CC, Pedraza-Chaverrí J (2013) Curcumin pretreatment prevents potassium dichromate-induced hepatotoxicity, oxidative stress, decreased respiratory complex I activity, and membrane permeability transition pore opening. Evidence-Based Complementary and Alternative Medicine. https://doi.org/10.1155/2013/424692

Goldberg DM, Spooner RJ (1983) Assay of Glutathione Reductase; HV Bergmeyen Methods of enzymatic analysis, $3{ }^{\text {rd }}$ Edition, Vol. 3, Verlog Chemie, Deerfiled Beach, pp. 258-265.

Gülçin I, Oktay M, Küfrevioğlu OI, Aslan A (2002) Determination of antioxidant activity of lichen Cetrariaislandica (L) Ach. Journal of Ethnopharmacology 79, 325-9.

https://doi.org/10.1016/S0378-8741(01)00396-8

Hamadouche M, Baqué F, Lefevre N, Kerboull M (2008) Minimum 10-year survival of Kerboull cemented stems according to surface finish. Clinical Orthopaedics and Related Research 466, 3329. https://doi.org/10.1007/s11999-007-0074-6
Han X, Shen T, Lou H (2007) Dietary Polyphenols and Their Biological Significance. International Journal of Molecular Sciences 8, 950-988.

Jaffery EH, Brown AF, Kurilich AC, Keek AS, Matusheski N, Klein BP (2003) Variation in content of bioactive components in broccoli. Journal of Food Composition and Analysis 16, 323-330.

Jaishankar M, Mathew BB, Shah MS, Gowda KS (2014) Biosorption of few heavy metal ions using agricultural wastes. Journal of Environment Pollution and Human Health 2, 1-6. DOI:10.12691/jephh-2-1-1

Joe B, Vijaykumar M, Lokesh BR (2004) Biological properties of curcumin-cellular and molecular mechanisms of action. Critical Reviews in Food Science and Nutrition 44, 97-111.

https://doi.org/10.1080/10408690490424702

Jurczuk M, Moniuszko-Jakoniuk J, Brzóska MM (2006) Involvement of some low-molecular thiols in the peroxidative mechanisms of lead and ethanol action on rat liver and kidney. Toxicology 219, 11-21.

https://doi.org/10.1016/j.tox.2005.10.022

Kang JK, Kang HJ, Seo JH, Kim SO, Choi JH, Cho DY, Park CG, Lee HY (2009) Effects of fermented turmeric (Curcuma longa) by Bacillus natto supplementation on liver function and serum lipid parameters in mice. Journal of the Korean Society of Food Science and Nutrition 38, 430-435.

https://doi.org/10.3746/jkfn.2009.38.4.430

Karadede-Akin H, Unlü E (2007) Heavy metal concentrations in water, sediment, fish and some benthic organisms from Tigris river, Turkey. Environmental Monitoring and Assessment 131, 323-37. http://dx.doi.org/10.1007/s10661-006-9478-0

Karioti A, Fani E, Vincieri FF, Bilia AR (2011) Analysis and stability of the constituents of Curcuma longa and Harpagophytum procumbens tinctures by HPLCDAD and HPLC-ESI-MS. Journal of Pharmaceutical and Biomedical Analysis 55, 479-86.

https://doi.org/10.1016/j.jpba.2011.02.029

Kruijswijk H (1975) Clinical chemistry, Principles and technics. Clinica Chimica Acta 65, 249-250. https://doi.org/10.1016/0009-8981(75)90116-3.

Lee J, Park J, Choi J (1996) The antioxidant activity of Ecklonia stolonifera. Archives of Pharmacal Research 19, 223-227.

https://doi.org/10.1007/BF02976894 
Li HT, Feng L, Jiang WD, Liu Y, Jiang J, Li SH, Zhou XQ (2013) Oxidative stress parameters and anti-apoptotic response to hydroxyl radicals in fish erythrocytes: protective effects of glutamine, alanine, citrulline and proline. Aquatic Toxicology 126,169-79.

https://doi.org/10.1016/j.aquatox.2012.11.005

Li M, Yue GG, Tsui SK, Fung KP, Lau CB (2018) Turmeric extract, with absorbable curcumin, has potent anti-metastatic effect in vitro and in vivo. Phytomedicine 46,131-141.

https://doi.org/10.1016/j.phymed.2018.03.065

Lin X, Gu Y, Zhou Q, Mao G, Zou B, Zhao J (2016) Combined toxicity of heavy metal mixtures in liver cells. Journal of Applied Toxicology 36, 1163-72. https://doi.org/10.1002/jat.3283

Liu CM, Ma JQ, Sun YZ (2012) Puerarin protects the rat liver against oxidative stress-mediated DNA damage and apoptosis induced by lead. Experimental and Toxicologic Pathology 64, 575-82. https://doi.org/10.1016/j.etp.2010.11.016

Liu CM, Zheng GH, Ming QL, Chao C, Sun JM (2013) Sesamin protects mouse liver against nickel-induced oxidative DNA damage and apoptosis by the PI3K-Akt pathway. Journal of Agricultural and Food Chemistry 61, 1146-54. https://doi.org/10.1021/jf304562b

Liu N, Huo G, Zhang L, Zhang X (2003) Effect of Zingiber Officinale Rosc on lipid peroxidation in hyperlipidemia rats. Wei Sheng Yan Jiu 32, 22-3. Chinese. PMID: 12731279.

Maiti S, Chatterjee AK (2001) Effects on levels of glutathione and some related enzymes in tissues after an acute arsenic exposure in rats and their relationship to dietary protein deficiency. Archives of Toxicology 75, 531-7.

https://doi.org/10.1007/s002040100240

Mary CPV, Vijayakumar S, Shankar R (2018) Metal chelating ability and antioxidant properties of Curcumin-metal complexes - A DFT approach. Journal of Molecular Graphics and Modelling 79, 1-14. https://doi.org/10.1016/j.jmgm.2017.10.022

Mathews V, Binu P, Sauganth-Paul M, Abhilash M, Manju A, Nair R (2012) Hepatoprotective efficacy of curcumin against arsenic trioxide toxicity. Asian Pacific Journal of Tropical Biomedicine 2, S706-S711. https://doi.org/10.1016/S2221-1691(12)60300-1
Meyer SA, Kulkarni AP (2001) Hepatotoxicity. In: Hodgson E, Smart RC, editors. Introduction to Biochemical Toxicology. 3rd ed. New York: John Wiley and sons; 2001. pp 487-490.

Mohajeri M, Rezaee M, Sahebkar A (2017) Cadmiuminduced toxicity is rescued by curcumin: A review. Biofactors 10;43, 645-661.

https://doi.org/10.1002/biof.1376

Moss DW, Henderson AR, Kachmar JF (1987) Enzymes in: Tietz NW, ed. Fundamentals of clinical chemistry. $3^{\text {rd }}$ ed. Philadelphia: WB Saunders: pp 346-421.

Mukhtar S, Ghori I (2012) Antibacterial activity of aqueous and ethanolic extracts of garlic, cinnamon and turmeric against Escherichia coli ATCC 25922and Bacillus subtilis DSM 3256. International Journal of Applied Biology and Pharmaceutical Technology 3, 131-136.

Nawab A, Li G, Liu W, Lan R, Wu J, Zhao Y, Kang K, Kieser B, Sun C, Tang S, Xiao M, An L (2019) Effect of dietary curcumin on the antioxidant status of laying hens under high- temperature condition. Journal of Thermal Biology 86, 102449.

https://doi.org/10.1016/j.jtherbio.2019.102449

Nishikimi, M., Roa, N.A. and Yogi, K. (1972) The Occurrence of Supeoxide Anion in the Reaction of Reduced Phenazine Methosulfate and Molecular Oxygen. Biochemical Biophysical Research Communications, 46, 849-854.

http://dx.doi.org/10.1016/S0006-291X(72)80218-3

Nouzarian R, Tabeidian SA, Toghyani M, Ghalamkari G, Toghyani M (2011) Effect of turmeric powder on performance, carcass traits, humoral immune responses, and serum metabolites in broiler chickens. Journal of Animal and Feed Sciences 20, 389-400.

https://doi.org/10.22358/jafs/66194/2011

Ohkawa H, Ohishi N, Yagi K (1979) Assay for lipid peroxides in animal tissues by thiobarbituric acid reaction. Analytical Biochemistry 95, 351-8. https://doi.org/10.1016/0003-2697(79)90738-3

Palipoch S, Punsawad C, Koomhin P, Suwannalert P (2014) Hepatoprotective effect of curcumin and alphatocopherol against cisplatin-induced oxidative stress. BMC Complementary and Alternative Medicine 14, 111-118. https://doi.org/10.1186/1472-6882-14-111

Pari L, Prasath A (2008) Efficacy of caffeic acid in preventing nickel induced oxidative damage in liver of rats. Chemico-Biological Interactions 173, 77-83. https://doi.org/10.1016/j.cbi.2008.02.010 
Reddy AC, Lokesh BR (1994) Studies on the inhibitory effects of curcumin and eugenol on the formation of reactive oxygen species and the oxidation of ferrous iron. Molecular and Cellular Biochemistry 137, 1-8.

https://doi.org/10.1007/bf00926033

Ruff HA, Markowitz ME, Bijur PE, Rosen JF (1996) Relationships among blood lead levels, iron deficiency, and cognitive development in two-year-old children. Environmental Health Perspectives $104,180-5$.

https://doi.org/10.1289/ehp.96104180

Schaich KM, Tian X, Xie J (2015) Hurdles and pitfalls in measuring antioxidant efficacy: A critical evaluation of ABTS, DPPH, and ORAC assays. Journal of Functional Foods 14, 111-125. https://doi.org/10.1016/j.jff.2015.01.043

Schultze HE, Heremans JF (1966) Biology of human protein. Elsevier publishing company, Amsterdam, Saunders. pp 346-421.

Shalan MG, Mostafa MS, Hassouna MM, El-Nabi SE, El-Refaie A (2005) Amelioration of lead toxicity on rat liver with Vitamin $\mathrm{C}$ and silymarin supplements. Toxicology 206, 1-15.

https://doi.org/10.1016/j.tox.2004.07.006

Shan B, Cai YZ, Sun M, Corke H (2005) Antioxidant capacity of 26 spice extracts and characterization of their phenolic constituents. Journal of Agricultural and Food Chemistry 53, 7749-59. https://doi.org/10.1021/jf051513y

Sreejayan N, Rao MN (1994) Curcuminoids as potent inhibitors of lipid peroxidation. Journal of Pharmacy and Pharmacology 46, 1013-6.

https://doi.org/10.1111/j.2042-

7158.1994.tb03258.x

Su H, Li Z, FiatiKenston SS, Shi H, Wang Y, Song X, Gu Y, Barber T, Aldinger J, Zou B, Ding M, Zhao J, Lin X (2017) Joint Toxicity of Different Heavy Metal Mixtures after a Short-Term Oral Repeated-Administration in Rats. International Journal of Environmental Research and Public Health. 14, 1164.

https://doi.org/10.3390/ijerph14101164

Taib NT, Jarrar BM, Mubarak M (2004) Ultrastructural alterations in hepatic tissues of white rats (Rattus norvegicus) induced by lead experimental toxicity. Saudi Journal of Biological Sciences 11, 11-20.
Tirkey N, Kaur G, Vij G, Chopra K (2005) Curcumin, a diferuloylmethane, attenuates cyclosporine-induced renal dysfunction and oxidative stress in rat kidneys. BMC Pharmacology 5, 5-15. https://doi.org/10.1186/1471-2210-5-15

Wang D, Huang H, Zhou L, Li W, Zhou H, Hou G, Liu J, Hu L (2015) Effects of dietary supplementation with turmeric rhizome extract on growth performance, carcass characteristics, antioxidant capability, and meat quality of wenchang broiler chickens. Italian Journal of Animal Science 14, 344-349.

https://doi.org/10.4081/ijas.2015.3870

Wang J, Yang Z, Lin L, Zhao Z, Liu Z, Liu X (2012) Protective effect of naringenin against lead-induced oxidative stress in rats. Biological Trace Element Research 146, 354-9.

https://doi.org/10.1007/s12011-011-9268-6

Wang S, Shi X (2001) Molecular mechanisms of metal toxicity and carcinogenesis. Molecular and Cellular Biochemistry 222, 3-9. PMID: 11678608

Wu X, Cobbina SJ, Mao G, Xu H, Zhang Z, Yang L (2016) A review of toxicity and mechanisms of individual and mixtures of heavy metals in the environment. Environmental Science and Pollution Research (international) 23, 8244-59.

https://doi.org/10.1007/s11356-016-6333-x

Young DS (1990) Effects of drugs on clinical laboratory tests. $3^{\text {rd }}$ edition. 3, 6-12.

Yue GG, Kwok HF, Lee JK, Jiang L, Wong EC, Gao S, Wong HL, Li L, Chan KM, Leung PC, Fung KP, Zuo Z, Lau CB (2016) Combined therapy using bevacizumab and turmeric ethanolic extract (with absorbable curcumin) exhibited beneficial efficacy in colon cancer mice. Pharmacological Research 111, 43-57. https://doi.org/10.1016/j.phrs.2016.05.025

Zimmermann M (1983) Ethical guidelines for investigations of experimental pain in conscious animals. Pain 16, 109-110.

https://doi.org/10.1016/0304-3959(83)90201-4

Zuo Y, Chen H, Deng Y (2002) Simultaneous determination of catechins, caffeine and gallic acids in green, Oolong, black and pu-erh teas using HPLC with a photodiode array detector. Talanta 57, 307-16. https://doi.org/10.1016/s0039-9140(02)00030-9 